\title{
HUBUNGAN PENGETHUN PENGETAHUAN DENGAN KEJADIAN ANEMIA PADA IBU HAMIL DI PUSKESMAS TAMALANREA
}

\author{
Suhartatik $^{1}$, Andi Fatmawati ${ }^{2}$, Jamila Kasim ${ }^{3}$ \\ ${ }^{1}$ STIKES Nani Hasanuddin Makassar \\ ${ }^{2}$ STIKES Nani Hasanuddin Makassar \\ ${ }^{3}$ STIKES Nani Hasanuddin Makassar
}

Alamat Respondensi : (suhartatik@stikesnh.ac.id/081342999419)

\begin{abstract}
ABSTRAK
Anemia adalah suatu keadaan adanya penurunan kadar hemoglobin, hematokrit, dan sejumlah eritrosit dibawah normal. Menurut WHO Normal hemoglobin pada ibu hamil adalah $\geq 11$. Tujuan penelitian ini adalah untuk mengetahui hubungan pengetahuan dan budaya dengan kejadian anemia pada ibu hamil di Puskesmas Tamalanrea. Penelitian ini adalah penelitian kuantitatif dengan menggunakan metode pendekatan rancangan Cross Sectional. Rancangan ini peneliti melakukan penelitian dan pengukuran hanya satu kali pada satu waktu. Adapun jumlah sampel dalam penelitian ini sebanyak 50 responden dengan menggunakan teknik Asidental sampling. Data dikumpulkan dari responden dengan menggunakan lembar kuesioner. Kemudian disajikan dalam tabel tabulasi dan uji statistik Chi-square dengan nilai kemaknaan 0.05. setelah dilakukan uji statistik menggunakan SPSS didapatkan hasil bivariat menunjukkan adanya hubungan yang signifikan antara pengetahuan dengan kejadian anemia pada ibu hamil $(p=0.020)$ dan adanya hubungan antara budaya dengan kejadian anemia pada ibu hamil ( $p=0.002$ ). berdasarkan penelitian tersebut dapat disimpulkan bahwa ada hubungan antara pengetahuan dan budaya dengan kejadian anemia pada ibu hamil.
\end{abstract}

Kata Kunci : Kejadian Anemia, Budaya, Pengetahuan, Ibu Hamil

\section{PENDAHULUAN}

Menurut Kemenkes RI (2014), Data

Word Health Organization (WHO)

menyebutkan bahwa total penderita anemia pada ibu hamil di Indonesia adalah $70 \%$, artinya dari 10 ibu hamil, sebanyak 7 orang akan menderita anemia. Menurut data Riset Kesehatan Dasar pada tahun 2013, prevalensi anemia ibu hamil di Indonesia sebesar 37\% mengalami peningkatan dari tahun 2007 sebanyak 24,5\% (Purwaningtyas M.L. \& Prameswari N.G., 2017).

Anemia merupakan suatu keadaan adanya penurunan kadar hemoglobin, hematokrit dan jumlah eritrosit dibawah nilai normal. Pada penderita anemia, lebih sering disebut kurang darah, kadar sel darah merah (Hemoglobin/Hb) dibawah nilai normal (Rukiyah Y.A. \& Yulianti L, 2015)

Pengetahuan adalah sesuatu yang diketahui berkaitan dengan proses pembelajaran. Proses belajar ini dipengaruhi berbagai faktor dari dalam, seperti motivasi dan faktor luar berupa sarana informasi yang tersedia, serta keadaan sosial budaya. Dalam wekipadia, pengetahuan adalah informasi atau maklumat yang diketahui atau disadari oleh seseorang (Budiman \& A., 2013)

Pantangan dan keharusan makan makanan tertentu, yang diajarkan secara turun temurun dalam setiap kebudayaan, dalam ukuran-ukuran tertentu dapat memberikan ketenangan yang diperlukan dalam kepentingan kesehatan jiwa. Namun, adat memantang makanan, keharusan mengkonsumsi makanan tertentu, dan pantang perbuatan tidak selalu memberikan dampak kesehatan yang baik, meskipun dilandasi oleh tujuan pencegahan bahaya (Indriyani \& Asmuji, 2014)

Dari uraian latar belakang di atas, peneliti tertarik untuk melakukan penelitian mengenai Hubungan Pengetahuan dan Budaya dengan Kejadian Anemia pada Ibu Hamil di Puskesmas Tamalanrea.

\section{BAHAN DAN METODE}

Lokasi, Populasi, dan Sampel

Berdasarkan permasalahn yang diteliti, maka jenis penelitian yang digunakan adalah penelitian kuantitatif dengan metode pendekatan rancangan Cross Sectional. Penelitian ini telah dilaksanakan pada tanggal 27 Juni - 30 Juli 2018. Lokasi penelitian ini telah dilakukan di Puskesmas Tamalanrea. Populasi dalam penelitian ini adalah seluruh ibu hamil di Puskesmas Tamalanrea pada bulan Februari sebanyak 50 orang dan sampel dalam penelitian ini sebanyak 50 responden.

1. Kriteria inklusi

a. Seluruh ibu hamil yang ada di Puskesmas Tamalanrea 
b. Ibu hamil yang hadir pada saat penelitian

2. Kriteria Eksklusi pada penelitian ini adalah sebagai berikut:

a. Ibu hamil yang tidak ikut konsultasi di Puskesmas Tamalanrea

b. Ibu hamil yang tidak siap untuk diteliti

Pungumpulan Data

1. Data primer

Data primer yaitu data yang diperoleh secara langsung dengan melakukan sendiri pengumpulan (wawancara, angket, kuesioner, observasi, test) terhadap objek. Data masih merupakan data mentah yang belum mengalami proses analisis.

2. Data sekunder

Data sekunder yaitu data yang berasal dari olahan data primer. Data sekunder biasanya didapatkan dari instansi pengumpulan data seperti Badan Pusat Statistik, Dinas Kesehatan, Rumah Sakit, Puskesmas dll (Ariani, 2014)

\section{Pengolahan Data}

1. Editing (penyuntingan data)

Hasil yang dikumpulkan melalui kuesioner disunting terlebih dahulu.

2. Coding (Membuat lembaran kode)

Lembaran kode adalah instrumen berupa kolom-kolom untuk merekam data secara manual.Lembaran berisi nomor responden dan nomor pertanyaan.

3. Processing (Memasukkan data) Jawaban dari masing-masing responden yang dalam bentuk kode dimasukkan ke dalam program SPSS for window.

4. Cleaning (Pembersihan data)

Apabila semua data dari sumber data atau responden selesai dimasukkan, perlu dicek kembali untuk melihat kemungkinan adanya kesalahan kode, kemudian dilakukan pembetulan.

\section{Analisis Data}

1. Analisis Univariat

Analisa univariat digunakan untuk menghitung distribusi frekuensi sehingga diketahui gambaran karakteristik responden.

2. Analisis Bivariat

Analisa bivariat untuk menganalisa 2 data yang saling berhubungan. Langkah awal dalam analisa data yaitu dengan melakukan uji normalitas data menggunakan uji chi square dengan nilai signifikan $\alpha \leq 0,05$. Dikatakan ada pengaruh dependen dengan independen apabila $p<0,05$
HASIL PENELITIAN

1. Analisis Univariat

Tabel 1. Distribusi Karakteristik Responden di Puskesmas Tamalanrea

\begin{tabular}{|c|c|c|}
\hline \multicolumn{3}{|l|}{ Karakteristik } \\
\hline Umur & & \\
\hline $17-25$ & 10 & 20 \\
\hline $26-35$ & 38 & 76 \\
\hline $36-45$ & 2 & 4 \\
\hline \multicolumn{3}{|l|}{ Pendidikan } \\
\hline SD & 4 & 8 \\
\hline SMP & 11 & 22 \\
\hline SMA & 14 & 28 \\
\hline DIII/S1 & 19 & 38 \\
\hline Lainnya & 2 & 4 \\
\hline \multicolumn{3}{|l|}{ Pekerjaan } \\
\hline IRT & 39 & 78 \\
\hline PNS & 3 & 6 \\
\hline WIRASWASTA & 8 & 16 \\
\hline
\end{tabular}

Tabel 1. menunjukkan bahwa jumlah responden yang berumur 26-35 tahun lebih dominan sebanyak 38 responden (76\%), yang memiliki pendidikan DIII/S1 lebih dominan sebanyak 19 responden (38\%), dan pekerjaan IRT lebih dominan sebanyak 39 responden (78\%).

2. Analisis Bivariat

Tabel 2.. Hubungan antara Pengetahuan Ibu Hamil tentang Anemia dengan Kejadian Anemia di Puskesmas Tamalanrea

\begin{tabular}{|c|c|c|c|c|c|c|}
\hline \multirow{3}{*}{ Pengetahuan } & \multicolumn{3}{|l|}{ Kejadian Anemia } & \multirow{2}{*}{ Total } \\
\cline { 2 - 6 } & $\begin{array}{c}\text { Tidak } \\
\text { Anemia }\end{array}$ & \multicolumn{2}{|c|}{ Anemia } & \multicolumn{2}{l}{} \\
\cline { 2 - 6 } & $\mathrm{n}$ & $\%$ & $\mathrm{n}$ & $\%$ & $\mathrm{n}$ & $\%$ \\
\hline Baik & 13 & 26 & 6 & 12 & 19 & 38 \\
\hline Kurang & 10 & 20 & 21 & 42 & 31 & 62 \\
\hline Total & 23 & 46 & 27 & 54 & 50 & 100 \\
\hline Uji Statistik Chi-square $:(\alpha)=0.05$ \\
$P=0.020$ & $\mathrm{n}=50$ \\
\hline
\end{tabular}

Tabel 2. menunjukkan bahwa dari 50 responden, terdapat 19 responden (38\%) yang memiliki pengetahuan baik dan dari data tersebut terdapat 13 responden (26\%) yang tidak menderita penyakit anemia dan 6 responden (12\%) yang terdiagnosis menderita penyakit anemia. Sedangkan responden yang memiliki pengetahuan kurang didapatkan 31 responden (62\%) yang memiliki pengetahuan kurang, 10 responden $(20 \%)$ yang tidak menderita anemia dan 21 responden (42\%) yang terdiagnosa menderita penyakit anemia.

Dari hasil analisis SPSS dengan menggunakan Uji Statistik Chi-square didapatkan $p=0.020$ sedangkan $\alpha=0.05$. Terlihat probabilitas dibawah 0.05 $(0.020<0.05)$ yang menunjukkan penolakan 
terhadap hipotesis nol $(\mathrm{H} 0)$ dan penerimaan terhadap hipotesis alternatif (Ha). Jadi dapat disimpulkan bahwa terdapat hubungan antara pengetahuan ibu hamil tentang anemia dengan kejadian anemia.

Tabel 3. Hubungan Antara Budaya dengan Kejadian Anemia di Puskesmas Tamalanrea

\begin{tabular}{|c|c|c|c|c|c|c|}
\hline \multirow{3}{*}{ Budaya } & \multicolumn{4}{|c|}{ Kejadian Anemia } & \multirow{2}{*}{\multicolumn{2}{|c|}{ Total }} \\
\hline & \multicolumn{2}{|c|}{ Tidak Anemia } & \multicolumn{2}{|c|}{ Anemia } & & \\
\hline & $\mathrm{n}$ & $\%$ & $\mathrm{n}$ & $\%$ & $\mathrm{n}$ & $\%$ \\
\hline Baik & 18 & 36 & 9 & 18 & 27 & 54 \\
\hline Buruk & 5 & 10 & 18 & 36 & 23 & 46 \\
\hline Total & 23 & 46 & 27 & 54 & 50 & 100 \\
\hline \multicolumn{7}{|c|}{$\begin{array}{l}\text { Uji Statistik Chi-square : }(\alpha)=0.05 \\
\qquad P=0.002 \quad \mathrm{n}=50\end{array}$} \\
\hline
\end{tabular}

Tabel 3. menunjukkan bahwa dari 50 responden, terdapat 27 responden (54\%) yang memiliki budaya yang baik dan dari data tersebut terdapat 18 responden (36\%) yang tidak menderita penyakit anemia dan 9 responden (18\%) yang terdiagnosis menderita penyakit anemia. Sedangkan responden yang memiliki budaya yang buruk didapatkan 23 responden (46\%) dan 5 responden $(10 \%)$ yang tidak menderita anemia dan 18 responden (36\%) yang terdiagnosis menderita penyakit anemia.

Dari hasil analisis SPSS dengan menggunakan Uji Statistik Chi-square didapatkan $p=0.002$ sedangkan $\alpha=0.05$. terlihat probabilitas dibawah 0.05 $(0.002<0.05)$ yang menunjukkan penolakan terhadap hipotesis nol (HO) dan penerimaan terhadap hipotesis alternatif (Ha). Jadi dapat disimpulkan bahwa terdapat hubungan antara budaya dengan kejadian anemia.

\section{PEMBAHASAN}

1. Hubungan antara Pengetahuan Ibu Hamil tentang Anemia dengan Kejadian Anemia Berdasarkan hasil penelitian yang telah dilakukan bahwa dari 50 responden, terdapat 19 responden (38\%) yang memiliki pengetahuan baik dan dari data tersebut terdapat 13 responden (26\%) yang tidak menderita penyakit anemia dan 6 responden (12\%) yang terdiagnosis menderita penyakit anemia. Sedangkan responden yang memiliki pengetahuan kurang didapatkan 31 responden (62\%) yang memiliki pengetahuan kurang, 10 responden $(20 \%)$ yang tidak menderita anemia dan 21 responden (42\%) yang terdiagnosa menderita penyakit anemia.
Dari hasil analisis SPSS dengan menggunakan Uji Statistik Chi-square didapatkan $p=0.020$ sedangkan $\alpha=0.05$. Terlihat probabilitas dibawah 0.05 $(0.020<0.05)$ yang menunjukkan penolakan terhadap hipotesis nol $(\mathrm{H} 0)$ dan penerimaan terhadap hipotesis alternatif (Ha). Jadi dapat disimpulkan bahwa terdapat hubungan antara pengetahuan ibu hamil tentang anemia dengan kejadian anemia.

Hasil penelitian ini sejalan dengan penelitian A., S., \& SA Noviawati, (2016) mengatakan bahwa dari penelitian yang dilakukan terhadap 48 responden. Diperoleh sebagian besar responden mempunyai pengetahuan yang kurang tentang anemia (43,8\%). Hasil Analisis bivariat menggunakan Chi-square menunjukkan bahwa variabel pengetahuan ibu tentang anemia mempunyai hubungan yang sangat signifikan dengan kejadian anemia dengan nilai $p$ sebesar 0.038 .

Hasil penelitian ini sejalan dengan penelitian (Purbadewi L. \& N.Y, 2013) mengatakan bahwa dari penelitian yang dilakukan terhadap 42 responden dan didapatkan 27 responden yang mengalami anemia sebanyak 8 orang $(29.6 \%)$ yang memiliki tingkat pengetahuan tentang anemia dalam kategori baik dan 19 orang $(70.4 \%)$ memiliki tingkat pengetahuan tentang anemia dalam kategori kurang. Dari 15 responden yang tidak mengalami anemia sebanyak 13 orang (86.7\%) memiliki pengetahuan tentang anemiadalam kategori baik dan 2 orang (13.3\%) memiliki tingkat pengetahuan tentang anemia dalam kategori kurang.

Hasil analisis dengan menggunakan Chi-square menunjukkan nilai Chi-square hitung $\left(X^{2}\right)$ sebesar 12.548. Berdasarkan nilai df (Degree of Freedom) sebesar 1 dan taraf signifikansi $5 \%$ diketahui $\mathrm{X}^{2}$ tabel sebesar 3.841 . hal ini berarti bahwa $X^{2}$ hitung $>X^{2}$ tabel $(12.584>3.841)$. selain itu dapat dilihat dari nilai $p$ yaitu sebesar $0.000<0.05(p<\alpha)$, berarti ada hubungan tingkat pengetahuan tentang anemia dengan kejadian anemia pada ibu hamil di Puskesmas Moyudan Sleman Yogyakarta.

Sehubungan dengan hal tersebut, peneliti menyimpulkan bahwa pengetahuan ibu hamil tentang anemia sangat mempengaruhi perilaku ibu hamil. Pengetahuan yang kurang tentang anemia akan berakibat pada kurang optimalnya perilaku kesehatan ibu hamil untuk mencegah terjadinya anemia kehamilan. Ibu hamil yang memiliki pengetahuan yang 
kurang tentang anemia mengakibatkan ibu hamil kurang mengkonsumsi makanan yang mengandung zat besi selama kehamilan terjadi.

Menurut Waryana, kekurangan zat besi akan beresiko terhadap janin dan ibu hamil sendiri. Janin akan mengalami gangguan atau hambatan pada pertumbuhan, baik sel tubuh maupun sel otak. Selain itu juga dapat mengakibatkan kematian pada janin dalam kandungan, abortus, cacat bawaan, dan BBLR (Rezeki S.N., A., \& S.N.Y, 2015)

2. Hubungan antara Budaya dengan Kejadian Anemia

Berdasarkan hasil penelitian yang telah dilakukan bahwa dari 50 responden, terdapat 27 responden (54\%) yang memiliki budaya yang baik dan dari data tersebut terdapat 18 responden (36\%) yang tidak menderita penyakit anemia dan 9 responden (18\%) yang terdiagnosis menderita penyakit anemia. Sedangkan responden yang memiliki budaya yang buruk didapatkan 23 responden $(46 \%)$ dan 5 responden (10\%) yang tidak menderita anemia dan 18 responden (36\%) yang terdiagnosis menderita penyakit anemia.

Dari hasil analisis SPSS dengan menggunakan Uji Statistik Chi-square didapatkan $p=0.002$ sedangkan $\alpha=0.05$. Terlihat probabilitas dibawah 0.05 $(0.002<0.05)$ yang menunjukkan penolakan terhadap hipotesis nol $(\mathrm{H} 0)$ dan penerimaan terhadap hipotesis alternatif (Ha). Jadi dapat disimpulkan bahwa terdapat hubungan antara budaya dengan kejadian anemia.

Budaya yang dimaksud dalam penelitian ini adalah makanan pantangan pada daerah. Menurut Wibowo, (1993), dampak positif menjalankan pantangan pada wanita hamil untuk tidak mengkonsumsi memakan buah pisang, nanas, ketimun dan lain-ain jenis makanan tertentu. Buah-buahan tersebut jika dimakan akan menimbulkan pengaruh pada kondisi kesehatan ibu hamil. Jika wanita sedang mengandung mengkonsumsi buah nanas dan durian akan menyebabkan rasa panas pada perut. Rasa panas ini timbul karena efek gas yang dihasilkan oleh buah-buahan tersebut dan hal itu tidak baik bagi kesehatan ibu dan janin yang dikandungnya. 7 Temuan dari hasil penelitian Fauziah C A di daerah Aceh juga menggambarkan hal yang sama, ada makanan bagi ibu hamil meliputi larangan memakan makanan yang dianggap tajam, seperti nanas, dikhawatirkan mengalami keguguran (Kasnodihardjo \& Kristiana, 2013)

Penelitian ini sejalan dengan penelitian mengatakan bahwa mayoritas ibu hamil berpantang makan ikan di usia > 7 bulan 38,88\%,di ikuti (Pasaribu D.R, F.T, \& Lusiana, 2014) dengan pantangan lainnya seperti berpantang makan jantung pisang 31,48\%,berpantang makan kerak nasi dan cabai rawit 29,62 \%,makan tape $25,92 \%$,makan ketan 24,07 \%,makan banyak di usia kehamilan tua $22,22 \%$ dan berpantang makan durian dan nenas 20,37 $\%$. Dari wawancara dengan ibu hamil, mereka menyatakan bahwa berpantang makan ikan di usia > 7 bulan dikhawatirkan jika bersalin atau nifas nanti darah yang keluar akan berbau amis,sementara dalam teori bahwa bau amis pada masa nifas itu di akibatkan dari masa transisi perubahan lochea yang terjadi karena adanya perubahan pada bagian desidua di rahim.dan alam teori Almatsier (2009) mengenai konsep dasar ilmu gizi mengungkapkan bahwa jika dilakukan pembatasan mengenai konsumsi ikan saat kehamilan yang merupakan sumber protein dapat mengakibatkan terjadi masalah pada pembentukan dan perkembangan janin saat kehamilan, sebenarnya kandungan protein itu dalam ikan memiliki kandungan nilai protein 16,0 dan ikan juga disebutkan memiliki sumber protein hewani yang mempunyai susunan asam amino yang paling sesuai dengan kebutuhan manusia.

Pantang makanan durian dan tape ibu hamil mengatakan dapat membahayakan kehamilan dan hal ini sejalan dalam teori Rafi (2009) mengungkapkan durian dan tape memiliki kandungan alkohol yang menghasilkan panas tubuh sehingga berpotensi menimbulkan bahaya pada janin diantaranya dapat menyebabkan perdarahan atau keguguran.sementara untuk pantangan makan nanas yang di katakan dapat menyebabkan keguguran tidak sesuai dengan teori Rafi (2009) yang menyebutkan bahwa sebaiknya selama hamil sebenarnya bukan tidak boleh mengkonsumsi nanas tapi harus ada pembatasan konsumsi nanas yang dalam nanas itu mengandung asam yang berlebihan sehingga dapat memacu peningkatan kadar asam lambung.

Sehubungan dengan hal tersebut, peneliti menyimpulkan bahwa budaya pantangan makan juga mempengaruhi terjadinya kejadian anemia. Ibu hamil yang memiliki budaya yang buruk lebih tinggi 
beresiko menderita penyakit anemia, sedangkan yang memiliki budaya yang baik lebih rendah beresiko terkena penyakit anemia. Namun tidak semua budaya ibu hamil yang buruk mengalami anemia karena masih banyak factor lain yang mempengaruhi terjadinya penyakit anemia pada ibu hamil seperti sosial ekonomi, pendidikan, dll.

\section{KESIMPULAN}

1. Terdapat hubungan yang signifikan antara pengetahuan ibu hamil tentang anemia dengan kejadian anemia pada ibu hamil $p<\alpha(0.020<0.05)$.
2. Terdapat hubungan yang signifikan antara budaya dengan kejadian anemia pada ibu hamil $p<\alpha(0.002<0.05)$

\section{SARAN}

1. Perlunya petugas kesehatan melakukan pendidikan kesehatan pada ibu hamil tentang pentingnya mengkonsumsi tablet $\mathrm{Fe}$

2. menyarankan kepada peneliti selanjutnya untuk memperdalam penelitian tentang hubungan pengetahuan dan budaya dengan kejadian anemia pada ibu hamil untuk memperoleh hasil yang lebih memuaskan

\section{DAFTAR PUSTAKA}

A., M., S., S., \& SA Noviawati, D. (2016). Hubungan Tingkat Pengetahuan dengan Kejadian Anemia Pada Ibu Hamil Di Wilayah Puskesmas Godean I, Vol. 9 (1), 1-10.

Ariani, A. P. (2014). Aplikasi Metodologi Peneletian Kebidanan dan Kesehatan Reproduksi. Yogyakarta: Nuha Medika.

Budiman, \& A., R. (2013). Kapita Selekta Kuesioner Pengetahuan dan Sikap dalam Penelitian Kesehatan. Jakarta Selatan: Salemba Medika.

Indriyani, D., \& Asmuji. (2014). Buku Ajar Keperawatan Maternitas. Yogyakarta: Ar-Ruzz Media.

Kasnodihardjo, \& Kristiana, L. (2013). Praktek Budaya Perawatan Kehamilan di Desa Gadingsari Yogyakarta, Vol. 3 (3), 113-123.

Pasaribu D.R, F.T, S., \& Lusiana, G. (2014). Sosial, Budaya Serta Pengetahuan Ibu Hamil yang Tidak Mendukung Kehamilan Sehat, Vol. 9 (1), 72-78.

Purbadewi L., \& N.Y, U. S. (2013). Hubungan Tingkat Pengetahuan tentang Anemia dengan Kejadian Anemia pada Ibu Hamil, Vol. 2 (1), 31-39.

Purwaningtyas M.L., \& Prameswari N.G. (2017). Faktor Kejadian Anemia pada Ibu Hamil. HIGEA Journal of Public Health Research and Development, VOL. 1 (3), 43-54.

Rezeki S.N., A., R., \& S.N.Y, U. (2015). Hubungan Kepatuhan Minum Tablet Besi dan Status Gizi lbu Hamil dengan Berat Badan Bayi Lahir di UPT Puskesmas Gondosari Kecamatan Gebog Kabupaten Kudus, VOI. $4(1), 1-7$.

Rukiyah Y.A., \& Yulianti L. (2015). Asuhan Kebidanan Patologi Kebidanan (Edisi 4). Jakarta Timur: CV. Trans Info Media. 